\title{
African Miocene dicot woods with two new records for this epoch from Egypt
}

\section{W. El-Saadawi ${ }^{\text {a }}$, M. M. Kamal El-Din ${ }^{\text {a }}$, M. H. Darwish ${ }^{\mathrm{b}, 1}$ and R. Osman ${ }^{\mathrm{c}}$}

${ }^{a}$ Department of Botany, Faculty of Science, University of Ain Shams, Cairo, Egypt

bepartment of Botany, College of Women for Science, Arts and Education, University of Ain Shams

${ }^{\mathrm{c}}$ Department of Geology, Faculty of Science, University of Benha, Benha, Egypt

Corresponding author monahd2000@yahoo.com

W. El-Saadawi, M. M. Kamal El-Din, M. H. Darwish and R. Osman, 2014. African Miocene dicot woods with two new records for this epoch from Egypt. Taeckholmia 34: 124.

\begin{abstract}
A summary is given on the African Miocene dicot woods. Egypt is the second richest African country after Ethiopia in Miocene dicot woods. Fabaceae is the largest family regarding the number of wood species in Africa and Egypt. Miocene dicot woods from Wadi Natrun area in Egypt were examined and two new records: Dalbergioxylon dicorynioides-Fabaceae and Sapindoxylon stromeriSapindaceae are reported. Xylotomical features indicate that the former was a large tree while the latter was a shrub or small tree and that a nonseasonal tropical palaeoclimate is suggested for the Miocene of the growth area.
\end{abstract}

Key words: African Miocene, Egypt, Fossil wood anatomy, Fabaceae, Sapindaceae, palaeoclimate. 


\section{Introduction}

Fossil dicot woods exist from Cretaceous to Quaternary in many African countries (Gregory et al., 2009). Hitherto, about 400 fossil dicot woods have been reported through this span of time from Africa (Gros, 1992; Dupéron-Laudoueneix \& Dupéron, 1995; Gregory et al., 2009; ElSaadawi et al., 2011, 2014; Cantrill et al., 2013; Kamal El-Din et al., 2014), with 115 types recorded from the Miocene (Table 1). One-hundred and nine of the 115 African Miocene dicot woods are related to 25 families including eight unnamed wood types while six are incertae sedis. It has to be mentioned also that three of the 25 families (i.e. Fagaceae?, Rutaceae? and Sapindaceae?) are recorded with question marks. About half of the woods are related to Fabaceae and Combretaceae while other families are either fairly (7-3 species) or poorly (2-1 species) represented.

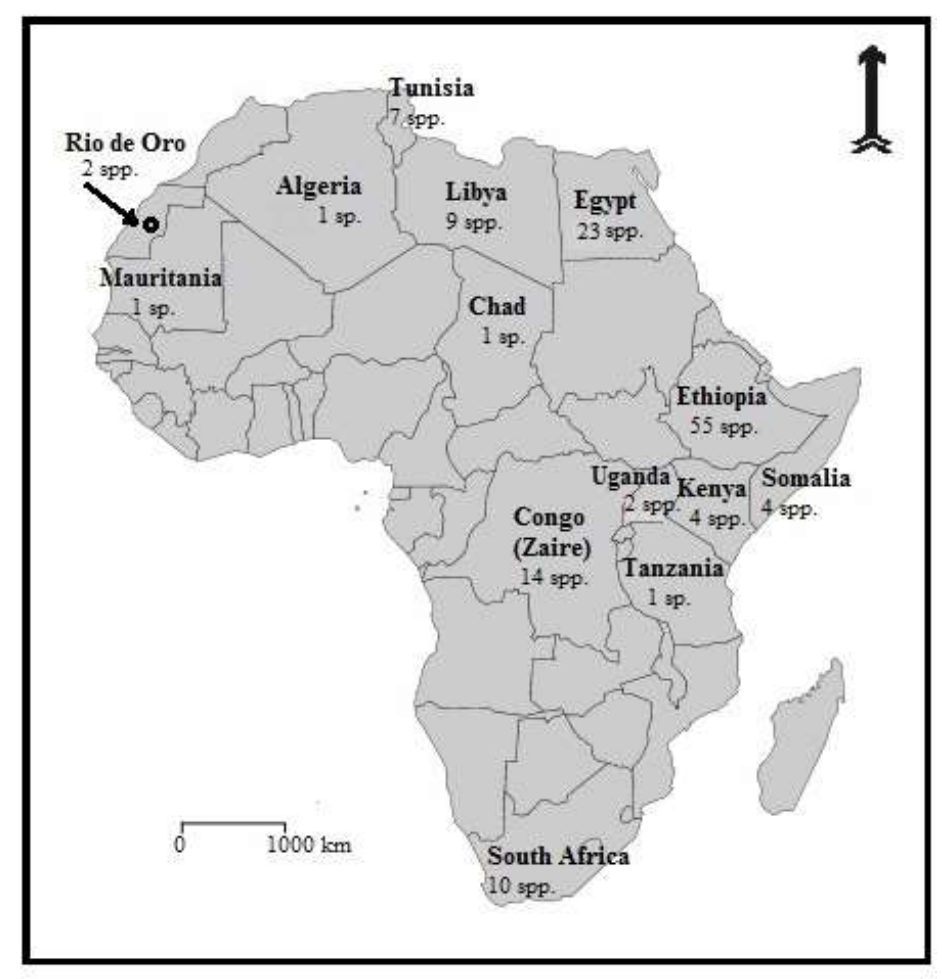

Figure 1. Map of Africa showing the number of the Miocene dicot wood species reported from 14 countries. 
The woods were reported from 14 African countries (Fig. 1). The largest number of woods (55 species) came from Ethiopia followed by Egypt (23 species) while other countries have but small numbers (Fig. 1).

Bombacoxylon owenii-Malvaceae sensu lato is the most widespread species in Africa (5 countries) followed by Detarioxylon aegyptiacumFabaceae (4 countries) then Glutoxylon symphonioides-Anacardiaceae and Terminalioxylon intermedium-Combretaceae (each from 3 countries) and 8 species are reported, each from 2 countries while the majority (103 species) are reported, each from one country (Table 1).

Table (1): Names of the 115 Miocene dicot woods of Africa, their families and the countries they are reported from. ( $\mathrm{M}=$ Miocene) (based on: Kräusel, 1939; Lemoigne, 1978; Dupéron-Laudoueneix \& Dupéron, 1995; Gregory et al., 2009; El-Saadawi et al., 2014; Kamal El-Din et al., 2014). Gregory et al. (2009, page 122) said that Sapindoxylon stromeri was recorded from Miocene of North Africa which is incorrect because Kräusel (1939, page 73) and Dupéron-Laudoueneix and Dupéron (1995, pages 452, 462 \& 467) mentioned that it was only recorded from Oligocene/Miocene of Egypt), therefore not mentioned in the table.

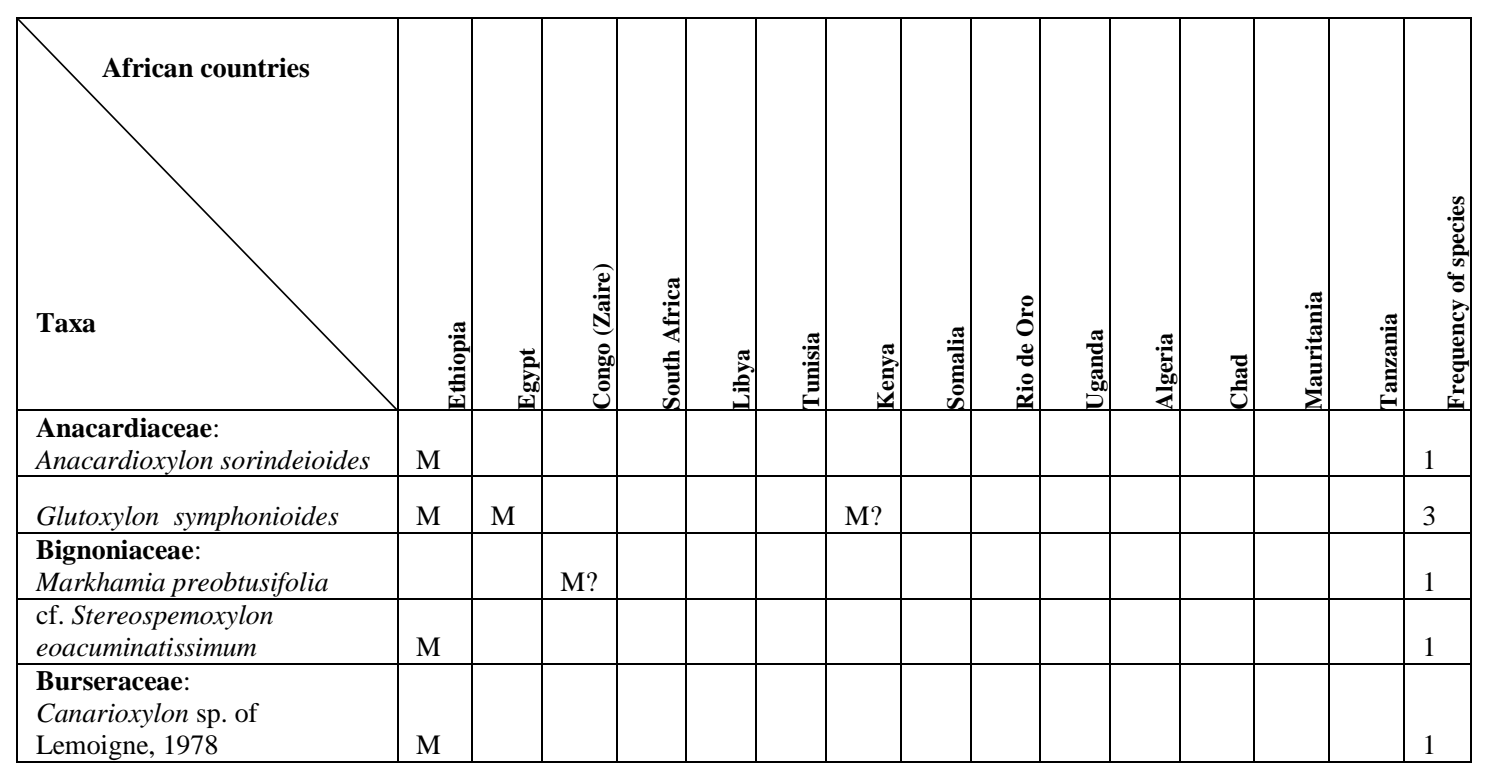


4

\begin{tabular}{|c|c|c|c|c|c|c|c|c|c|c|c|c|c|c|c|}
\hline African countries & 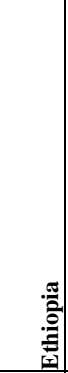 & 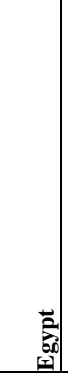 & 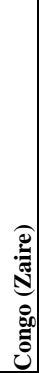 & 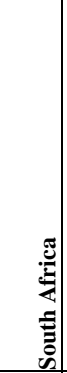 & 晃| & 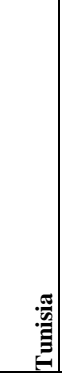 & : & 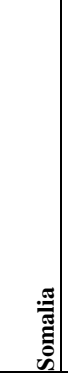 & 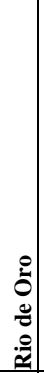 & 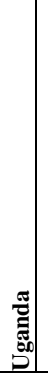 & 产 & 胥 & 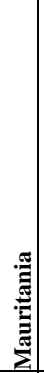 & 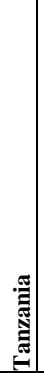 & 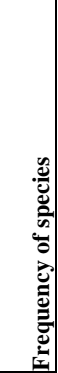 \\
\hline $\begin{array}{l}\text { Chrysobalanaceae: } \\
\text { Parinarioxylon itersonii }\end{array}$ & M & & & & & & & & & & & & & & 1 \\
\hline $\begin{array}{l}\text { Clusiaceae (including } \\
\text { Hypericaceae) = Guttiferae: } \\
\text { Callophylloxylon garcinioides }\end{array}$ & M & & & & & & & & & & & & & & 1 \\
\hline Guttiferoxlon abyssinica & $\mathrm{M}$ & & & & & & & & & & & & & & 1 \\
\hline Guttiferoxlon amphimasoides & $\mathrm{M}$ & & & & & & & & & & & & & & 1 \\
\hline Guttiferoxylon fareghense & & M & & & & & & & & & & & & & 1 \\
\hline Mammeoxylon lanneoides & M & & & & & & & & & & & & & & 1 \\
\hline $\begin{array}{l}\text { Combretaceae: } \\
\text { Combretoxylon desrotoris }\end{array}$ & $\mathrm{M}$ & & & & & & & & & & & & & & 1 \\
\hline $\begin{array}{l}\text { Combretoxylon sp. of } \\
\text { Beauchamp, Lemoigne and } \\
\text { Petescu, 1973a, b }\end{array}$ & M? & $\mathrm{M}$ & & & & & & & & & & & & & 2 \\
\hline $\begin{array}{l}\text { Combretoxylon sp. of } \\
\text { Lemoigne, } 1978\end{array}$ & $\mathrm{M}$ & & & & & & & & & & & & & & 1 \\
\hline Combretum imberbe & & & & M & & & & & & & & & & & 1 \\
\hline Terminalioxylon chowdhurii & & & & M & & & & & & & & & & & 1 \\
\hline Terminalioxylon doubingeri & $\mathrm{M}$ & & & & & & & & & & & & & & 1 \\
\hline Terminalioxylon geinitzii & & M & & & & & & & & & & & & & 1 \\
\hline Terminalioxylon intermedium & & $\mathrm{M}$ & & & M & & & $\mathrm{M}$ & & & & & & & 3 \\
\hline Terminalioxylon primigenum & & M & & & & & & & & & & & & & 1 \\
\hline $\begin{array}{l}\text { Terminalioxylon sp. of } \\
\text { Lemoigne, Beauchamp and } \\
\text { Samule, } 1974\end{array}$ & $\mathrm{M}$ & & & & & & & & & & & & & & 1 \\
\hline Terminalioxylon tunesense & & & & & & $\mathrm{M}$ & & & & & & & & & 1 \\
\hline cf. Terminalioxylon edwardsii & & $\mathrm{M}$ & & & & & & & & & & & & & 1 \\
\hline $\begin{array}{l}\text { Combretaceae?: } \\
\text { unnamed wood of Wheeler, } \\
\text { Wiemann and Fleagle, } 2007\end{array}$ & $\mathrm{M}$ & & & & & & & & & & & & & & 1 \\
\hline $\begin{array}{l}\text { Connaraceae: } \\
\text { Byrsocarpus tertiara }\end{array}$ & M? & & & & & & & & & & & & & & 1 \\
\hline $\begin{array}{l}\text { Dipterocarpaceae: } \\
\text { Dipterocarpoxylon africanum }\end{array}$ & & $\mathrm{M}$ & & & & & & & & & & & & & 1 \\
\hline
\end{tabular}


African Miocene dicot woods with two new records ......

\begin{tabular}{|c|c|c|c|c|c|c|c|c|c|c|c|c|c|c|c|}
\hline African countries & 竝 & 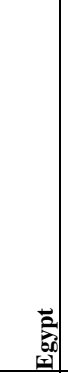 & 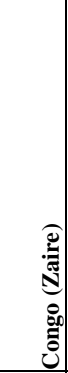 & 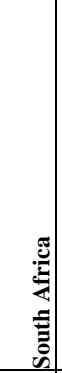 & 晃 & 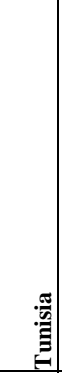 & |ֶ: & 爱 & 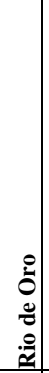 & 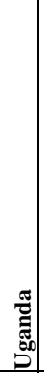 & 离 & 胥 & 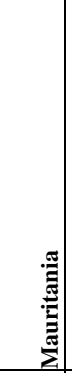 & 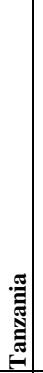 & 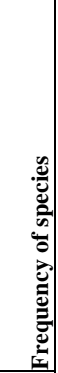 \\
\hline $\begin{array}{l}\text { Dipterocarpoxylon } \\
\text { monoteoide }\end{array}$ & $\mathrm{M}$ & & & & & & & & & & & & & & 1 \\
\hline $\begin{array}{l}\text { Monotes sp. of Bamford and } \\
\text { De Wit, } 1993\end{array}$ & & & & M & & & & & & & & & & & 1 \\
\hline $\begin{array}{l}\text { Euphorbiaceae: } \\
\text { Euphorbioxylon aethiopicum }\end{array}$ & $\mathrm{M}$ & & & & & & & & & & & & & & 1 \\
\hline $\begin{array}{l}\text { Euphorbioxylon } \\
\text { cleistanthoides }\end{array}$ & $\mathrm{M}$ & & & & & & & & & & & & & & 1 \\
\hline Euphorbioxylon uapacoides & M & & & & & & & & & & & & & & 1 \\
\hline $\begin{array}{l}\text { Fabaceae: } \\
\text { cf. Acacia sp. of Wheeler, } \\
\text { Wiemann and Fleagle, } 2007 \\
\text { (Mimosoideae) }\end{array}$ & M & & & & & & & & & & & & & & 1 \\
\hline $\begin{array}{l}\text { Afzelioxylon athiopicum } \\
\text { (Caesalpinioideae) }\end{array}$ & M & & & & & & & & & & & & & & 1 \\
\hline $\begin{array}{l}\text { Afzelioxylon welkittii } \\
\text { (Caesalpinioideae) }\end{array}$ & $\mathrm{M}$ & M & & & & & & & & & & & & & 2 \\
\hline $\begin{array}{l}\text { Albizia pregumifera } \\
\text { (Mimosoideae) }\end{array}$ & & & M & & & & & & & & & & & & 1 \\
\hline $\begin{array}{l}\text { Baphioxylon abyssinica } \\
\text { (Faboideae) }\end{array}$ & M & & & & & & & & & & & & & & 1 \\
\hline $\begin{array}{l}\text { Baphioxylon dechampsii } \\
\text { (Faboideae) }\end{array}$ & & & $\mathrm{M}$ & & & & & & & & & & & & 1 \\
\hline $\begin{array}{l}\text { Brachystegioxylon kaedense } \\
\text { (Caesalpinioideae) }\end{array}$ & & & & & & & & & & & & & M? & & 1 \\
\hline $\begin{array}{l}\text { Brachystegioxylon } \\
\text { premicrophyllum } \\
\text { (Caesalpinioideae) }\end{array}$ & $\mathrm{M}$ & & $\mathrm{M}$ & & & & & & & & & & & & 2 \\
\hline $\begin{array}{l}\text { Brachystegioxylon welkitii } \\
\text { (Caesalpinioideae) }\end{array}$ & $\mathrm{M}$ & & & & & & & & & & & & & & 1 \\
\hline $\begin{array}{l}\text { Caesalpinoxylon craense } \\
\text { (Caesalpinioideae) }\end{array}$ & & & & & $\mathrm{M}$ & & & & & & & & & & 1 \\
\hline $\begin{array}{l}\text { Caesalpinoxylon aff. } \\
\text { migiurtinum } \\
\text { (Caesalpinioideae) }\end{array}$ & & & & & & $\mathrm{M}$ & & & & & & & & & 1 \\
\hline $\begin{array}{l}\text { Caesalpinoxylon mogadaense } \\
\text { (Caesalpinioideae) }\end{array}$ & & & & & & & & & & & $\mathrm{M}$ & & & & 1 \\
\hline $\begin{array}{l}\text { Copaiferoxylon migiurtinum } \\
\text { (Caesalpinioideae) }\end{array}$ & & & & & & & & $\mathrm{M}$ & & & & & & & 1 \\
\hline $\begin{array}{l}\text { Craibioxylon welkitii } \\
\text { (Faboideae) }\end{array}$ & $\mathrm{M}$ & & & & & & & & & & & & & & 1 \\
\hline $\begin{array}{l}\text { Cynometroxylon } \\
\text { schlagintweitii }\end{array}$ & M & M & & & & & & & & & & & & & 2 \\
\hline
\end{tabular}


6

\begin{tabular}{|c|c|c|c|c|c|c|c|c|c|c|c|c|c|c|c|}
\hline African countries & 产 & $\underset{\overrightarrow{0}}{\overrightarrow{0} 0}$ & 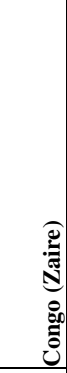 & 苞 & 愛 & : & 茎: & 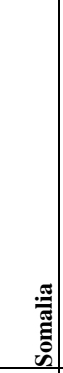 & 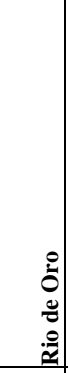 & 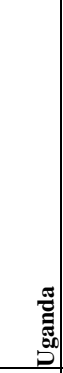 & $\frac{\pi}{4}$ & एٓ & 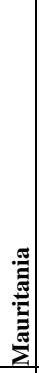 & 䒿 & 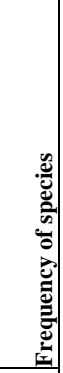 \\
\hline (Caesalpinioideae) & & & & & & & & & & & & & & & \\
\hline $\begin{array}{l}\text { Cynometroxylon tunesense } \\
\text { (Caesalpinioideae) }\end{array}$ & & $\mathrm{M}$ & & & & $\mathrm{M}$ & & & & & & & & & 2 \\
\hline $\begin{array}{l}\text { Cynometroxylon sp. cf. } C \text {. } \\
\text { holdenii (Caesalpinioideae) }\end{array}$ & & $\mathrm{M}$ & & & & & & & & & & & & & 1 \\
\hline $\begin{array}{l}\text { Cynometroxylon sp. of El- } \\
\text { Saadawi, Kamal El-Din, } \\
\text { Wheeler, El-Faramawi and El- } \\
\text { Noamani, 2014 } \\
\text { (Caesalpinioideae) }\end{array}$ & & $\mathrm{M}$ & & & & & & & & & & & & & 1 \\
\hline $\begin{array}{l}\text { Cynometroxylon sp. of } \\
\text { Wheeler, Wiemann and } \\
\text { Fleagle, } 2007 \\
\text { (Caesalpinioideae) }\end{array}$ & M & & & & & & & & & & & & & & 1 \\
\hline $\begin{array}{l}\text { Detarioxylon aegyptiacum } \\
\text { (Caesalpinioideae) }\end{array}$ & & M & & & $\mathrm{M}$ & & & M & $\mathrm{M}$ & & & & & & 4 \\
\hline $\begin{array}{l}\text { Dialioxylon aethiopicum } \\
\text { (Caesalpinioideae) }\end{array}$ & $\mathrm{M}$ & & & & & & & & & & & & & & 1 \\
\hline $\begin{array}{l}\text { Dialiumoxylon aethiopicum } \\
\text { (Caesalpinioideae) }\end{array}$ & M & & & & & & & & & & & & & & 1 \\
\hline $\begin{array}{l}\text { Dichrostachyoxylon } \\
\text { palaeonyassanum } \\
\text { (Mimosoideae) }\end{array}$ & & & M & & & & & & & M & & & & & 2 \\
\hline $\begin{array}{l}\text { Dichrostachyoxylon } \\
\text { sahabiense (Mimosoideae) }\end{array}$ & & & & & M & & & & & & & & & & 1 \\
\hline $\begin{array}{l}\text { Hopeoxylon aethiopicum } \\
\text { (Caesalpinioideae) }\end{array}$ & M & & & & & & & & & & & & & & 1 \\
\hline $\begin{array}{l}\text { Isoberlineoxylon congoense } \\
\text { (Caesalpinioideae) }\end{array}$ & & & M & & & & & & & & & & & & 1 \\
\hline $\begin{array}{l}\text { ?Leguminoxylon albizziae } \\
\text { (Mimosoideae) }\end{array}$ & & $\mathrm{M}$ & & & & & & & & & & & & & 1 \\
\hline $\begin{array}{l}\text { Milletioxylon embergeri } \\
\text { (Faboideae) }\end{array}$ & $\mathrm{M}$ & & & & & & & & & & & & & & 1 \\
\hline $\begin{array}{l}\text { Mimosaceoxylon lebacqii } \\
\text { (Mimosoideae) }\end{array}$ & & & $\mathrm{M}$ & & & & & & & & & & & & 1 \\
\hline $\begin{array}{l}\text { Mimosoxylon krameri } \\
\text { (Mimosoideae) }\end{array}$ & $\mathrm{M}$ & & & & & & & & & & & & & & 1 \\
\hline $\begin{array}{l}\text { Mimosoxylon tenax } \\
\text { (Mimosoideae) }\end{array}$ & & M & & & & & & & & & & & & & 1 \\
\hline $\begin{array}{l}\text { Pahudioxylon gehannemense } \\
\text { (Caesalpinioideae) }\end{array}$ & & & & & $\mathrm{M}$ & & & & & & & & & & 1 \\
\hline
\end{tabular}

W. El-Saadawi et al. 
African Miocene dicot woods with two new records ......

\begin{tabular}{|c|c|c|c|c|c|c|c|c|c|c|c|c|c|c|c|}
\hline African countries & 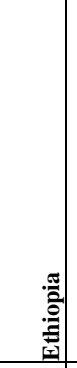 & $\begin{array}{c}\overrightarrow{0} \\
\text { a. } \\
\text { and } \\
\end{array}$ & 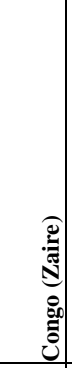 & 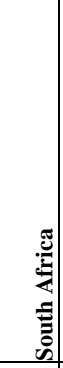 & 茪 & : & : & 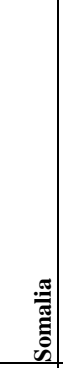 & 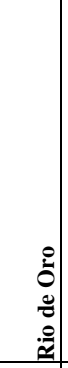 & 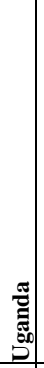 & 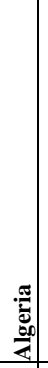 & चٓ & : & 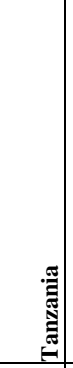 & 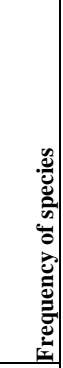 \\
\hline $\begin{array}{l}\text { Pahudioxylon sp. of Damblon, } \\
\text { Gerrienne, D'Outrelpont, } \\
\text { Delvaux, Beeckman and } \\
\text { Back, } 1998 \text { (Caesalpinioideae) }\end{array}$ & & & & & & & & & & & & & & M? & 1 \\
\hline $\begin{array}{l}\text { Peltophoroxylon embergeri } \\
\text { (Caesalpinioideae) }\end{array}$ & M & & & & & & & & & & & & & & 1 \\
\hline $\begin{array}{l}\text { Pentaclethra miocenica } \\
\text { (Mimosoideae) }\end{array}$ & & & M? & & & & & & & & & & & & 1 \\
\hline $\begin{array}{l}\text { Pterocarpoxylon syrtense } \\
\text { (Faboideae) }\end{array}$ & & & & & $\mathrm{M}$ & & & & & & & & & & 1 \\
\hline $\begin{array}{l}\text { Retama tamaricoides } \\
\text { (Faboideae) }\end{array}$ & & & & & & $\mathrm{M}$ & & & & & & & & & 1 \\
\hline $\begin{array}{l}\text { Retama sp. of Koeniguer, } \\
1974 \text { (Faboideae) }\end{array}$ & & & & & & M & & & & & & & & & 1 \\
\hline $\begin{array}{l}\text { Swartzioxylon naraens } \\
\text { (Faboideae) }\end{array}$ & & & & & & M & & & & & & & & & 1 \\
\hline $\begin{array}{l}\text { Tetrapleuroxylon acacia } \\
\text { (Mimosoideae) }\end{array}$ & & $\mathrm{M}$ & & & & & & & & & & & & & 1 \\
\hline $\begin{array}{l}\text { Tetrapleuroxylon ingaeforme } \\
\text { (Mimosoideae) }\end{array}$ & & $\mathrm{M}$ & & & & & & & & & & & & & 1 \\
\hline $\begin{array}{l}\text { unnamed wood of Wheeler, } \\
\text { Wiemann and Fleagle, } 2007\end{array}$ & M & & & & & & & & & & & & & & 1 \\
\hline $\begin{array}{l}\text { Fagaceae?: } \\
\text { unnamed wood of Bamford } \\
\text { and De Wit, } 1993\end{array}$ & & & & M & & & & & & & & & & & 1 \\
\hline $\begin{array}{l}\text { Irvingiaceae: } \\
\text { Irvingiaceoxylon dechampsii }\end{array}$ & $\mathrm{M}$ & & & & & & & & & & & & & & 1 \\
\hline $\begin{array}{l}\text { Lauraceae: } \\
\text { Laurinoxylon desioi }\end{array}$ & & & & & M & & & & & & & & & & 1 \\
\hline $\begin{array}{l}\text { Lecythidaceae: } \\
\text { Barringtonioxylon } \\
\text { allamblackioides } \\
\end{array}$ & $\mathrm{M}$ & & & & & & & & & & & & & & 1 \\
\hline $\begin{array}{l}\text { Malvaceae sensu lato: } \\
\text { Bombacoxylon bombacoides }\end{array}$ & & & & & & & M? & & & & & & & & 1 \\
\hline Bombacoxylon langstoni & & $\mathrm{M}$ & & & & & & & & & & & & & 1 \\
\hline Bombacoxylon owenii & & M & & & M & M & & M & $\mathrm{M}$ & & & & & & 5 \\
\hline Sterculioxylon giarabubense & & $\mathrm{M}$ & & & & & & & & & & & & & 1 \\
\hline $\begin{array}{l}\text { Meliaceae: } \\
\text { Carapoxylon cahenii }\end{array}$ & & & $\mathrm{M}$ & & & & & & & & & & & & 1 \\
\hline $\begin{array}{l}\text { Entandrophragma } \\
\text { cylindricum }\end{array}$ & & & & $\mathrm{M}$ & & & & & & & & & & & 1 \\
\hline
\end{tabular}


8

\begin{tabular}{|c|c|c|c|c|c|c|c|c|c|c|c|c|c|c|c|}
\hline African countries & 产高 & $\overrightarrow{0}$ & 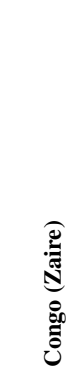 & 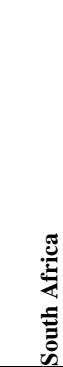 & ํํㄹำ & 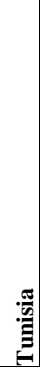 & : & : & 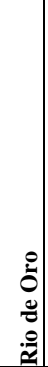 & 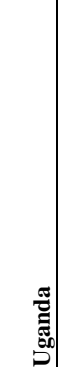 & $\frac{\pi}{20}$ & تٓ & 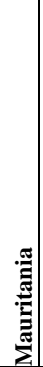 & 爱 & 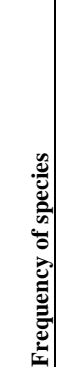 \\
\hline $\begin{array}{l}\text { Entandrophragmoxylon } \\
\text { boureaui }\end{array}$ & & & & M & & & & & & & & & & & 1 \\
\hline $\begin{array}{l}\text { Entandrophragmoxylon sp. of } \\
\text { Lemoigne, } 1978\end{array}$ & M & & & & & & & & & & & & & & 1 \\
\hline Paratrichilioxylon grambastii & $\mathrm{M}$ & & & & & & & & & & & & & & 1 \\
\hline Paratrichilioxylon ludovicii & $\mathrm{M}$ & & & & & & & & & & & & & & 1 \\
\hline Trichilia lanata & & & & M & & & & & & & & & & & 1 \\
\hline $\begin{array}{l}\text { Monimiaceae: } \\
\text { Xymaloxylon zeltenense }\end{array}$ & & & & & M & & & & & & & & & & 1 \\
\hline $\begin{array}{l}\text { Moraceae: } \\
\text { Ficoxylon blanckenhornii }\end{array}$ & $\mathrm{M}$ & $\mathrm{M}$ & & & & & & & & & & & & & 2 \\
\hline Ficoxylon cretaceum & M & M & & & & & & & & & & & & & 2 \\
\hline Myrianthoxylon chaloneri & M & & & & & & & & & & & & & & 1 \\
\hline $\begin{array}{l}\text { Myristicaceae: } \\
\text { Myristicoxylon ocoteoides }\end{array}$ & $\mathrm{M}$ & & & & & & & & & & & & & & 1 \\
\hline Myristicoxylon vincenti & & & & & & & & & & & & M? & & & 1 \\
\hline $\begin{array}{l}\text { Myristicaceae?: } \\
\text { unnamed wood of Bamford } \\
\text { and De Wit, } 1993\end{array}$ & & & & M & & & & & & & & & & & 1 \\
\hline $\begin{array}{l}\text { Oleaceae: } \\
\text { Ligustrum sp. of Bamford } \\
\text { and De Wit, } 1993\end{array}$ & & & & $\mathrm{M}$ & & & & & & & & & & & 1 \\
\hline Olea sp. of Chaney, 1933 & & & & & & & & & & M & & & & & 1 \\
\hline $\begin{array}{l}\text { Oleaceae?: } \\
\text { unnamed wood of Wheeler, } \\
\text { Wiemann and Fleagle, } 2007\end{array}$ & M & & & & & & & & & & & & & & 1 \\
\hline $\begin{array}{l}\text { Rutaceae?: } \\
\text { unnamed wood of Bamford } \\
\text { and De Wit, } 1993\end{array}$ & & & & $\mathrm{M}$ & & & & & & & & & & & 1 \\
\hline $\begin{array}{l}\text { unnamed wood of Wheeler, } \\
\text { Wiemann and Fleagle, } 2007\end{array}$ & $\mathrm{M}$ & & & & & & & & & & & & & & 1 \\
\hline $\begin{array}{l}\text { Sapindaceae?: } \\
\text { unnamed wood of Wheeler, } \\
\text { Wiemann and Fleagle, } 2007\end{array}$ & $\mathrm{M}$ & & & & & & & & & & & & & & 1 \\
\hline $\begin{array}{l}\text { Sapotaceae: } \\
\text { Chrysophyllum zairense }\end{array}$ & & & M? & & & & & & & & & & & & 1 \\
\hline Sapotoxylon acthiopicum & M & & & & & & & & & & & & & & 1 \\
\hline
\end{tabular}

W. El-Saadawi et al. 
African Miocene dicot woods with two new records ......

\begin{tabular}{|c|c|c|c|c|c|c|c|c|c|c|c|c|c|c|c|}
\hline African countries & : & 家. & 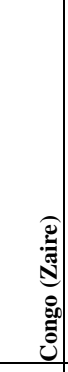 & 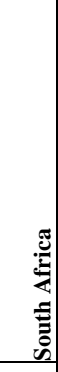 & 党: & 童 & 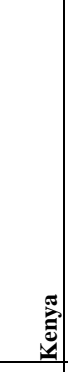 & 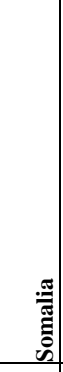 & \begin{tabular}{l|}
0 \\
0 \\
0 \\
0 \\
0 \\
0 \\
\end{tabular} & 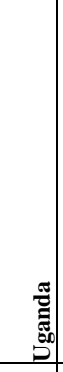 & 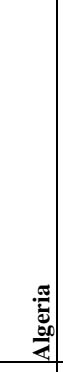 & ت్ & 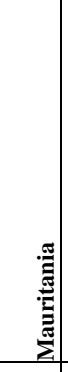 & 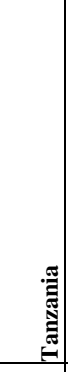 & 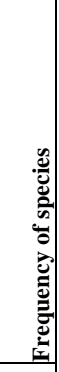 \\
\hline Sapotoxylon lecomtedoxoides & $\mathrm{M}$ & & & & & & & & & & & & & & 1 \\
\hline $\begin{array}{l}\text { Sapotoxylon sp. of Wheeler, } \\
\text { Wiemann and Fleagle, } 2007\end{array}$ & M & & & & & & & & & & & & & & 1 \\
\hline Tridesmostemon tertiarum & & & M? & & & & & & & & & & & & 1 \\
\hline $\begin{array}{l}\text { Urticaceae: } \\
\text { Myrianthoxylon chaloneri }\end{array}$ & $\mathrm{M}$ & & & & & & & & & & & & & & 1 \\
\hline $\begin{array}{l}\text { Verbenaceae: } \\
\text { Vitexoxylon aethiopicum }\end{array}$ & M & & & & & & & & & & & & & & 1 \\
\hline $\begin{array}{l}\text { Vitexoxylon sp. of Lemoigne, } \\
1978\end{array}$ & M & & & & & & & & & & & & & & 1 \\
\hline $\begin{array}{l}\text { Incertae sedis: } \\
\text { Dicotyloxylon sp. of } \\
\text { Lemoigne, Beauchamp and } \\
\text { Samule, } 1974 \\
\end{array}$ & M & & & & & & & & & & & & & & 1 \\
\hline Dryoxylon cabindense & & & M? & & & & & & & & & & & & 1 \\
\hline Dryoxylon drypeteoides & & & & & & & M? & & & & & & & & 1 \\
\hline Dryoxylon kenyense & & & & & & & M? & & & & & & & & 1 \\
\hline Dryoxylon lepwesonnei & & & M & & & & & & & & & & & & 1 \\
\hline Dryoxylon manzandiense & & & M? & & & & & & & & & & & & 1 \\
\hline Total species/country & 55 & 23 & 14 & 10 & 9 & 7 & 4 & 4 & 2 & 2 & 1 & 1 & 1 & 1 & \\
\hline
\end{tabular}

The 23 Miocene dicot wood species of Egypt come from 17 sites (see map in El-Saadawi et al., 2014; Kamal El-Din et al., 2014) and are related to seven families (Table 1) (Fabaceae (10 species: 6 Caesalpinioideae, 4 Mimosoideae and no Faboideae), Combretaceae (5 species), Malvaceae (3 species), Moraceae (2 species), Anacardiaceae, Clusiaceae and Dipterocarpaceae (one species for each)). B. owenii is also the most widespread species in Egypt (13 sites) followed by $T$. geinitzii and $T$. primigenium (5 sites each). Wadi Natrun is one of these Miocene Egyptian sites and in it, the present study area lies. 


\section{Study area}

The studied site lies near Deir Baramûs in Wadi Natrun, in the north of the Western Desert of Egypt, about $90 \mathrm{~km}$ northwest of Giza Pyramids, and about $25 \mathrm{~km}$ to the west of the nearest point on the Cairo-Alex. desert road (Mark 123 km) (Fig. 2) (Kamal El-Din, 1999). Neogene (Miocene and Pliocene) deposits are widely distributed in the north of Egypt, with Wadi Natrun strata belonging to the Miocene Moghra Formation (Said, 1962, 1971).

The strata of the section of Moghra Formation from top to base are as follows:

1. White sandy limestone; $5.50 \mathrm{~m}$,

2. Variegated sandstones: gray, yellow and brown; $12.5 \mathrm{~m}$,

3. Marly sandstone: yellowish in colour and various ostracods; $12.5 \mathrm{~m}$,

4. Variegated sandstone: $10 \mathrm{~m}$,

5. Yellow marl with gypsum veins and a lower bone bed; $37 \mathrm{~m}$,

6. Variegated sands with a bone bed, abundant silicified wood and vertebrate remains; $43 \mathrm{~m}$,

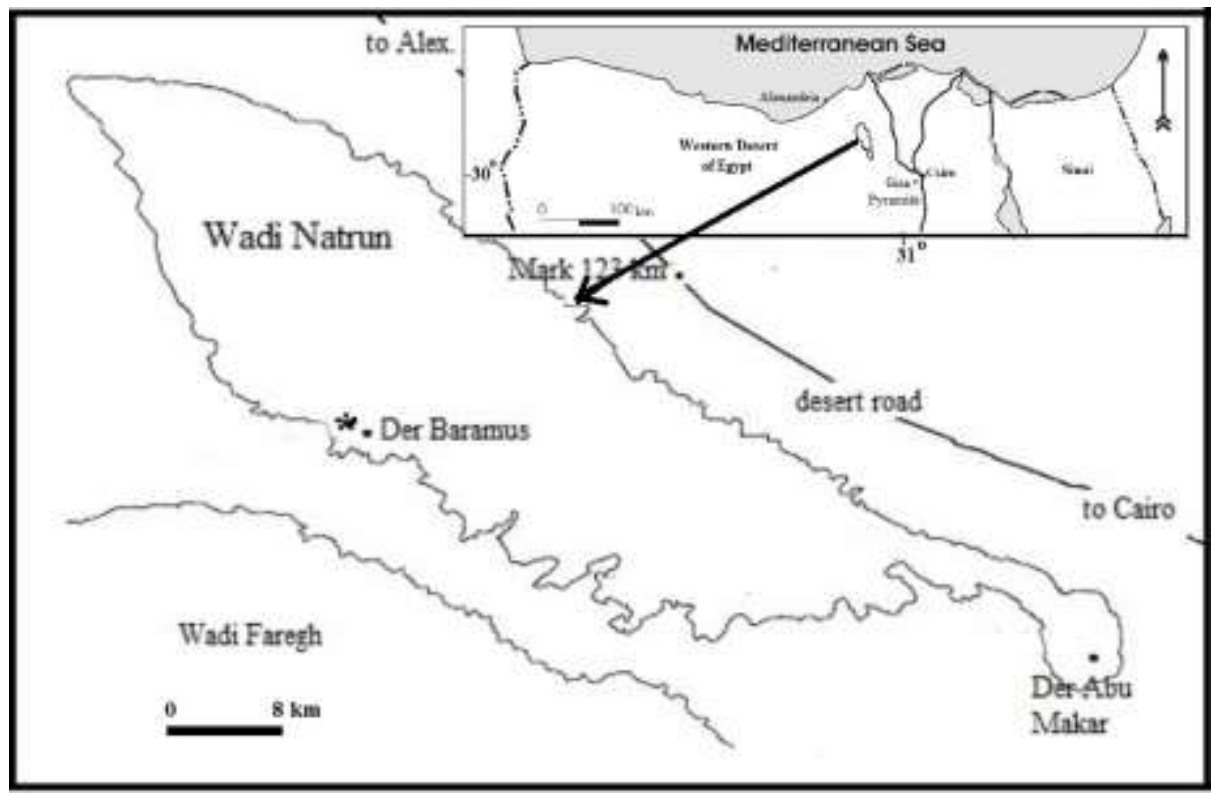

Figure 2. Map showing the northern part of the Western Desert of Egypt, Wadi Natrun and location of the study area*. 
7. Conglomeratic limestone bed: yellow, hard with abundant ostracods; $1 \mathrm{~m}$,

8. Variegated free-running sands with shale intercalations; $97 \mathrm{~m}$ (cf. Said, 1962).

Only one dicot wood species B. owenii (Kräusel, 1939) and three Palmoxylon species ( $P$. aschersoni, P. compactum \& P. libycum) (ElSaadawi et al., 2002, 2004) had been reported earlier from the Miocene of this area.

\section{Material and methods}

Seven specimens were collected by El-Saadawi, Kamal El-Din and Osman from loose fragments scattered on the sand surface ranging between $10-50 \mathrm{~cm}$ in length and $5-20 \mathrm{~cm}$ in diameter. Thin sections (transverse, tangential and radial) were made using techniques described by Andrews (1961). The specimens and slides are numbered from 1WN to 7WN (WN refers to Wadi Natrun; the study area) and housed in the palaeobotanical collection of the Botany Department, Faculty of Science, Ain Shams University, Cairo.

The description follows the IAWA Committee (1989) for hardwoods. The identification of fossil woods was performed by using the descriptions of Kräusel (1939), Müller-Stoll and Mädel (1967), El-Saadawi et al. (2011), the Insidewood (2004-on wards) and consulting relevant references. Systematic assignment follows the APG III (2009). Affinities were determined following Metcalfe and Chalk (1950) and other references that will be mentioned where appropriate. The Vulnerability Index (V) was calculated using the Carlquist (1977) equation and conductive capability (C) was calculated using the Wolfe and Upchurch (1987) equation.

\section{Results}

Two specimens (4WN \& 6WN) belonged to Bombacoxylon owenii (Malvaceae/Bombacoideae), one specimen (7WN) to Dalbergioxylon dicorynioides (Fabaceae/Faboideae), two specimens (1WN \& 5WN) to Sapindoxylon stromeri (Sapindaceae) and two specimens (2WN \& $3 \mathrm{WN})$ were ill-preserved dicot woods. D. dicorynioides and S. stromeri are new to the site and this is their first record from the Miocene age of Egypt in addition this is also the first record of Faboideae and Sapindaceae from this 
age in Egypt (see El-Saadawi et al., 2014). D. dicorynioides and S. stromeri are described and discussed in this paper.

\section{Descriptions and Affinities}

Order: Fabales Bromhead, 1838

Family: Fabaceae Lindl., 1836

Subfamily: Faboideae Rudd, 1972

Genus: Dalbergioxylon Ramanujam, 1960

Species: Dalbergioxylon dicorynioides Müller-Stoll and Mädel, 1967

(“Acacioxylon antiqumm" Schenk, 1883)

Growth rings indistinct or absent. Wood diffuse-porous. Vessels solitary and in radial multiples of 2-3. Solitary vessels rounded in outline, mean tangential diameter $170 \mu \mathrm{m}$ (range 100-210 $\mu \mathrm{m}$ ), mean radial diameter $200 \mu \mathrm{m}$ (range 160-250 $\mu \mathrm{m}$ ). Mean vessel frequency $8 / \mathrm{mm}^{2}$ (range 5-13/ $\mathrm{mm}^{2}$ ). Perforation plates simple with horizontal end walls. Intervessel pits alternate and vestured. Vessel-ray pits similar to intervessel pits in size and shape throughout the ray cell. Mean vessel element length $330 \mu \mathrm{m}$ (range 280-410 $\mu \mathrm{m})$. Axial parenchyma aliform, confluent and irregular banded (14 celled wide). Rays1-3 seriate, up to 20 cells high, homocellular. Fibers thick-walled, non-septate, pits not observed.

The most important anatomical features of the present fossil wood as: diffuse-porous wood, solitary and in radial multiples vessels, exclusively simple perforation plates, short-medium vessel element lengths, alternate vessel pitting, non-septate fibers, predominantly paratracheal, combinations of aliform, confluent and banded parenchyma and uniseriate to multiseriate rays are seen in tropical legumes (Fabaceae) also in Bignoniaceae, Meliaceae, Moraceae and tropical Sapindaceae. Of the families listed above only Fabaceae have vestured pitting (Wheeler \& Baas, 1992).

By using the Müller-Stoll and Mädel (1967) identification key for the genera of fossil legume woods: the features diffuse-porous wood, non septate fibers, up to 3 seriate rays and aliform or often confluent parenchyma with irregular tangential bands lead to Dalbergioxylon. The genus Dalbergioxylon has five species recorded from Oligocene to Miocene/Pliocene of Africa, Asia and Europe (Gregory et al., 2009; Tiwari et al., 2012): 1- Dalbergioxylon antiquum from Miocene/Pliocene of India (Ramanujam, 1960), 2- D. dicorynioides from Oligocene and Oligocene/Miocene of Egypt (Kräusel, 1939; El-Saadawi et al., 2011) and Oligocene of Tunisia (Fliche, 1888), 3- D. europaeum from Miocene of 
Europe (Burgh, 1973), 4- D. mizoramensis from Miocene/Pliocene of India (Tiwari et al., 2012) and 5- D. oligocenicum from Oligocene of France (Dupéron, 1979) (Table 2).

From Table (2), the present fossil wood is nearest to $D$. dicorynioides which was recorded earlier from Oligocene of Cairo Petrified Forest and Wadi Dugla (Kräusel, 1939; El-Saadawi et al., 2011) and Oligocene/Miocene of West of Giza Pyramids and Gebel El-KhashabNorthern Petrified Forest (Kräusel, 1939) (Fig. 3). Wood is the only macrofossil recorded from Egypt related to Dalbergia, however, worldwide there are many fossil leaflets and fruits of Dalbergia reported but they need to be reevaluated (Herendeen et al., 1992).

Table (2). Comparison of anatomical features among the Dalbergioxylon (based on: Kräusel, 1939; Insidewood 2004-onward; El-Saadawi et al., 2011; Tiwari et al., 2012).

\begin{tabular}{|c|c|c|c|c|c|c|}
\hline Feature & $\begin{array}{c}D . \\
\text { antiquum }\end{array}$ & $\begin{array}{c}D . \\
\text { dicorynioides }\end{array}$ & $\begin{array}{c}D . \\
\text { europaeum }\end{array}$ & $\begin{array}{c}\text { D. } \\
\text { mizoramensis }\end{array}$ & $\begin{array}{c}D . \\
\text { oligocenicum }\end{array}$ & $\begin{array}{c}\text { Present } \\
\text { specimen }\end{array}$ \\
\hline $\begin{array}{l}\text { Growth } \\
\text { rings }\end{array}$ & Present & Absent & $\begin{array}{l}\text { Present or } \\
\text { absent }\end{array}$ & Absent & Present & Absent \\
\hline Wood & $\begin{array}{l}\text { Diffuse- } \\
\text { porous }\end{array}$ & $\begin{array}{l}\text { Diffuse- } \\
\text { porous }\end{array}$ & $\begin{array}{l}\text { Diffuse- } \\
\text { porous }\end{array}$ & $\begin{array}{l}\text { Diffuse- } \\
\text { porous }\end{array}$ & $\begin{array}{l}\text { Semi-ring- } \\
\text { porous }\end{array}$ & $\begin{array}{l}\text { Diffuse- } \\
\text { porous }\end{array}$ \\
\hline $\begin{array}{l}\text { Vessel } \\
\text { tangential } \\
\text { diameter }\end{array}$ & $\begin{array}{l}>=\quad 200 \\
\mu \mathrm{m}\end{array}$ & $\begin{array}{l}100-230 \mu \mathrm{m} \\
(180)\end{array}$ & $\begin{array}{l}<=50, \quad 50- \\
100 \mu \mathrm{m}\end{array}$ & $88-241 \mu \mathrm{m}$ & $50-100 \mu \mathrm{m}$ & $\begin{array}{l}100-210 \\
\mu \mathrm{m}(170)\end{array}$ \\
\hline Vessels/mm² & $5-20$ & $5-6(12)$ & $\begin{array}{l}?<=5, ? \quad 5- \\
20, \quad ? 20-40, \\
? 40-100, \quad ? \\
>=100\end{array}$ & $20-40$ & $20-40$ & $5-13(8)$ \\
\hline $\begin{array}{l}\text { Vessel } \\
\text { element } \\
\text { length } \mu \mathrm{m}\end{array}$ & $\begin{array}{l}?<=350, \\
? 350- \\
800, \\
?>=800\end{array}$ & $300-450$ & $\begin{array}{l}?<=350, \\
? 350-800\end{array}$ & $209-595$ & $<=350$ & $\begin{array}{l}280-410 \\
(330)\end{array}$ \\
\hline Parenchyma & $\begin{array}{l}\text { Aliform, } \\
\text { confluent } \\
\text { and } \\
\text { banded } \\
\text { (up to } 3 \\
\text { and more } \\
\text { than 3) }\end{array}$ & $\begin{array}{l}\text { Aliform, } \\
\text { confluent and } \\
\text { banded }(1-5)\end{array}$ & $\begin{array}{l}\text { Confluent, } \\
\text { banded (up } \\
\text { to } 3 \text { and } \\
\text { more than } \\
\text { 3) and } \\
\text { marginal or } \\
\text { submarginal }\end{array}$ & $\begin{array}{l}\text { Vasicentric to } \\
\text { aliform, } \\
\text { confluent and } \\
\text { banded (4-10) }\end{array}$ & $\begin{array}{l}\text { Diffuse, } \\
\text { unilateral, } \\
\text { aliform, } \\
\text { confluent, } \\
\text { banded (1-3) } \\
\text { and marginal } \\
\text { or } \\
\text { submarginal }\end{array}$ & $\begin{array}{l}\text { Aliform, } \\
\text { confluent } \\
\text { and } \\
\text { banded } \\
(1-4)\end{array}$ \\
\hline Rays & $\begin{array}{l}1-3 \\
\text { seriate }\end{array}$ & $1-3$ seriate & $\begin{array}{l}1-3 \text { seriate } \\
\text { and large } \\
\text { rays } \\
\text { commonly } \\
4-10 \text { seriate }\end{array}$ & $\begin{array}{l}1-2 \text { seriate } \\
\text { (mostly } 2 \text { ) }\end{array}$ & $1-3$ seriate & $\begin{array}{l}1-3 \\
\text { seriate }\end{array}$ \\
\hline
\end{tabular}


Order: Sapindales Dumort., 1829

Family: Sapindaceae Juss., 1789

Genus: Sapindoxylon Kräusel, 1922

Species: Sapindoxylon stromeri Kräusel, 1939

Growth rings indistinct or absent. Wood diffuse-porous. Vessels solitary and often in radial multiples of 2-5 (mostly 2-3). Solitary vessels rounded to oval in outline, mean tangential diameter $75 \mu \mathrm{m}$ (range 60-95 $\mu \mathrm{m})$, mean radial diameter $90 \mu \mathrm{m}$ (range 80-105 $\mu \mathrm{m}$ ). Mean vessel frequency $32 / \mathrm{mm}^{2}$ (range $26-40 / \mathrm{mm}^{2}$ ). Perforation plates simple with horizontal to oblique end walls. Intervessel pits alternate. Vessel-ray pits similar to intervessel pits in size and shape throughout the ray cell. Mean vessel element length $390 \mu \mathrm{m}$ (range 290-500 $\mu \mathrm{m}$ ). Axial parenchyma scanty paratracheal. Rays 1-3 seriate mostly uniseriate, homocellular. Fibers non-septate, thick-walled. Crystals abundant in the rays.

The most important anatomical features of the present fossil wood as: diffuse-porous wood, small vessels, solitary and often in radial multiples of up to 5 vessels, scanty paratracheal parenchyma, mostly uniseriate rays indicate affinity with some members of modern Anacardiaceae, Burseraceae, Combretaceae (Terminalia), Rutaceae, Sapindaceae and Simarubiaceae (Pearson \& Brown, 1932; Metcalfe \& Chalk, 1950). A few members belonging to Anacardiaceae resemble the present fossil in having scanty parenchyma and uniseriate rays but generally in Anacardiaceae woods are ring-porous. The woods of Burseraceae differ in having intercellular canals. Terminalia-Combretaceae resembles the fossil in having multiples of vessels and uniseriate rays but the parenchyma and pits (vestured) are different. The woods of Rutaceae have multiples of vessels and uniseriate rays but differ in vasicentric parenchyma. Some Simarubiaceae show certain features common with the present fossil but differ in having ring-porous woods and multiseriate rays. The present fossil wood characters are met with in some genera of the Sapindaceae as Arytera, Euphoria, Litchi, Mischocarpus, Otonephelium, Pometia and Schleichera (Navale, 1957; Mehrotra et al., 1999). Vessel size and frequency are different in Euphoria, Litchi, Otonephelium, Pometia and Schleichera from the present fossil. The present fossil wood characters match well with Arytera and Mischocarpus. Kräusel (1922) instituted the genus 
Sapindoxylon for fossil woods showing anatomical characters comparable to Sapindaceae.

Genus Sapindoxylon has 28 species worldwide in: Africa, Asia, Europe North America and South America (Gregory et al., 2009). Eight of them were recorded from Upper Cretaceous/Eocene to Quaternary of Africa (Dupéron-Laudoueneix \& Dupéron, 1995; Gregory et al., 2009): 1Sapindoxylon almelai from Miocene/Pliocene of Rio de Oro (Koeniguer, 1967a), 2- S. haile-sellassiei from Oligocene/Miocene of Ethiopia (Lemoigne, 1970), 3- S. koholense from Tertiary of Algeria (Koeniguer, 1976), 4- S.(?) lapparentii from Miocene/Pliocene and Quaternary of Chad (Koeniguer, 1968,1975), 5- S. mbaense from Eocene of Senegal (Koeniguer, 1973), 6- S. stromeri from Oligocene and Oligocene/Miocene of Egypt (Kräusel, 1939), 7- S. sp. of Koeniguer from Tertiary of Libya (Koeniguer, 1967b) and 8- S. sp. of Beauchamp, Lemoigne and Petrescu from Upper Cretaceous/Eocene of Ethiopia (Beauchamp et al., 1973a,b).

Table (3). Comparison of anatomical features of African Sapindoxylon species and the present fossil wood (based on Kräusel, 1939; Beauchamp et al., 1973b; Insidewood 2004-onwards).

\begin{tabular}{|c|c|c|c|c|c|c|c|c|c|}
\hline Species & S. almelai & $\begin{array}{l}\text { S. haile- } \\
\text { sellassiei }\end{array}$ & $\begin{array}{c}\text { S. } \\
\text { koholense }\end{array}$ & $\begin{array}{c}.(?) \\
\text { lapparentii }\end{array}$ & S. mbaense & $\begin{array}{c}S . \\
\text { stromeri }\end{array}$ & $\begin{array}{c}S . \text { sp. of } \\
\text { Koeniguer } \\
1967 \mathrm{~b}\end{array}$ & $\begin{array}{c}\text { S. sp. of } \\
\text { Beauchamp, } \\
\text { Lemoigne } \\
\text { and } \\
\text { Petrescu } \\
\text { 1973b }\end{array}$ & $\begin{array}{c}\text { Present } \\
\text { specimens }\end{array}$ \\
\hline Wood & $\begin{array}{l}\text { Ring, semi- } \\
\text { ring porous }\end{array}$ & $\begin{array}{l}\text { Diffuse- } \\
\text { porous }\end{array}$ & $\begin{array}{l}\text { Diffuse- } \\
\text { porous }\end{array}$ & $\begin{array}{l}\text { Ring- } \\
\text { porous }\end{array}$ & $\begin{array}{l}\text { Diffuse- } \\
\text { porous }\end{array}$ & $\begin{array}{l}\text { Diffuse- } \\
\text { porous }\end{array}$ & $\begin{array}{l}\text { Diffuse- } \\
\text { porous }\end{array}$ & $\begin{array}{l}\text { Diffuse- } \\
\text { porous }\end{array}$ & $\begin{array}{l}\begin{array}{l}\text { Diffuse- } \\
\text { porous }\end{array} \\
\end{array}$ \\
\hline Vessels & $\begin{array}{l}\text { In radial } \\
\text { multiples of } \\
4 \text { or more } \\
\text { common }\end{array}$ & - & - & $\begin{array}{l}\text { In radial } \\
\text { multiples } \\
\text { of } 4 \text { or } \\
\text { more } \\
\text { common }\end{array}$ & $\begin{array}{l}\text { Exclusively } \\
\text { solitary } \\
\text { (90\% or } \\
\text { more) }\end{array}$ & $\begin{array}{l}\text { Solitary } \\
\text { and in } \\
\text { radial } \\
\text { multiples } \\
\text { of } 4 \text { or } \\
\text { more } \\
\text { common }\end{array}$ & $\begin{array}{l}\text { In radial } \\
\text { multiples } \\
\text { of } 4 \text { or } \\
\text { more } \\
\text { common }\end{array}$ & $\begin{array}{l}\text { Solitary and } \\
\text { in radial } \\
\text { multiples of } \\
2-5\end{array}$ & $\begin{array}{l}\text { Solitary } \\
\text { and in } \\
\text { radial } \\
\text { multiples } \\
\text { of } 2-5\end{array}$ \\
\hline $\begin{array}{l}\text { Tangential } \\
\text { diameter }\end{array}$ & $\begin{array}{l}100-200 \\
\mu \mathrm{m}\end{array}$ & $\begin{array}{l}100-200 \\
\mu \mathrm{m}\end{array}$ & $\begin{array}{l}100-200 \\
\mu \mathrm{m}\end{array}$ & $\begin{array}{l}100-200 \\
\mu \mathrm{m}\end{array}$ & $50-100 \mu \mathrm{m}$ & $\begin{array}{l}65-100 \\
\mu \mathrm{m}\end{array}$ & $50-100 \mu \mathrm{m}$ & $>=200 \mu \mathrm{m}$ & $60-95 \mu \mathrm{m}$ \\
\hline Vessels/mm ${ }^{2}$ & $5-20$ & $5-20$ & $<=5$ & $\begin{array}{l}20-40,40- \\
100\end{array}$ & $5-20,20-40$ & $\begin{array}{l}20-40 \\
(25-30)\end{array}$ & $20-40$ & $\begin{array}{l}5-20 \\
(8-12)\end{array}$ & $26-40$ \\
\hline $\begin{array}{l}\text { Vessel } \\
\text { element } \\
\text { length }\end{array}$ & $\begin{array}{l}350-800 \\
\mu \mathrm{m}\end{array}$ & $\begin{array}{l}350-800 \\
\mu \mathrm{m}\end{array}$ & $\begin{array}{l}350-800 \\
\mu \mathrm{m}\end{array}$ & $<=350 \mu \mathrm{m}$ & $350 \mu \mathrm{m}$ & $\begin{array}{l}300-800 \\
\mu \mathrm{m}\end{array}$ & $<=350 \mu \mathrm{m}$ & $\begin{array}{l}<=350-800 \\
\mu \mathrm{m}\end{array}$ & $\begin{array}{l}290-500 \\
\mu \mathrm{m}\end{array}$ \\
\hline Parenchyma & $\begin{array}{l}\text { Vasicentric, } \\
\text { confluent }\end{array}$ & $\begin{array}{l}\text { Diffuse, } \\
\text { scanty, } \\
\text { vasicentric, } \\
\text { aliform }\end{array}$ & $\begin{array}{l}\text { Absent or } \\
\text { scanty }\end{array}$ & $\begin{array}{l}\text { Scanty, } \\
\text { vasicentric }\end{array}$ & Scanty & Scanty & $\begin{array}{l}\text { Absent or } \\
\text { rare }\end{array}$ & Vasicentric & Scanty \\
\hline Rays & $\begin{array}{l}\text { Exclusively } \\
\text { uniseriate }\end{array}$ & $\begin{array}{l}1-3 \text { seriate, } \\
\text { mostly } \\
\text { uniseriate }\end{array}$ & $\begin{array}{l}1-3 \\
\text { seriate }\end{array}$ & $\begin{array}{l}\text { exclusively } \\
\text { uniseriate }\end{array}$ & $\begin{array}{l}\text { exclusively } \\
\text { uniseriate }\end{array}$ & $\begin{array}{l}1-3 \\
\text { seriate, } \\
\text { mostly } \\
\text { uniseriate }\end{array}$ & $1-3$ seriate & 2-6 seriate & $\begin{array}{l}1-3 \\
\text { seriate, } \\
\text { mostly } \\
\text { uniseriate }\end{array}$ \\
\hline
\end{tabular}


The anatomical details of the present fossil wood and its comparisons with the other species of Sapindoxylon recorded from Africa (Table 3) show that the present fossil wood is related to S. stromeri.

In Egypt, S. stromeri was recorded earlier from Oligocene of north of Birket Qerûn and Qatrani Formation (?) and Oligocene/Miocene of Giza Pyramids (Kräusel, 1939) (Fig. 3). The fossil woods are the only macrofossils recorded in Egypt related to family Sapindaceae. There are other macrofossils as Sapindosis (leaf fragment) from Cretaceous of Sudan (Klitzsch \& Lejal Nicol, 1984).

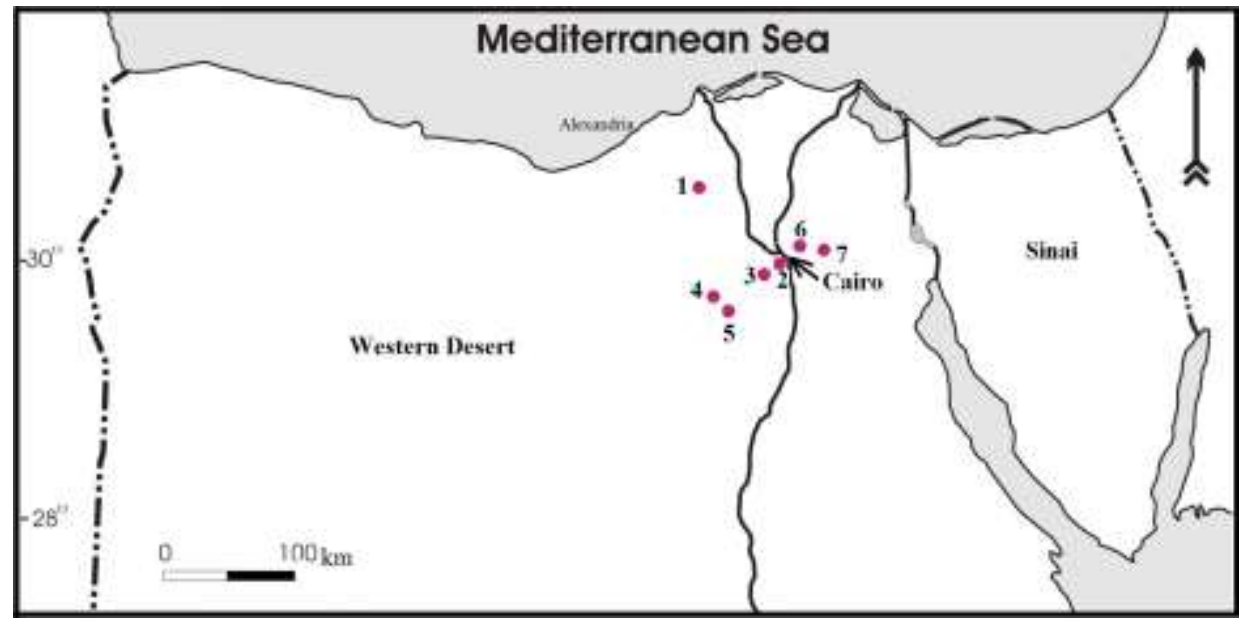

Figure 3. Map of Egypt showing sites of occurrence of Dalbergioxylon dicorynioides $(1,2$, $3,6 \& 7)$ and Sapindoxylon stromeri $(1,2,4 \& 5) .1$ - Present study area in Wadi Natrun, 2- Giza Pyramids, 3- Gebel El Khashab (Northern Petrified Forest), 4Qatrani, 5- Birket Qerûn, 6- Wadi Dugla, 7- Cairo Petrified Forest

As a result of this work, the known Miocene dicot wood flora of Wadi Natrun and Egypt increased from 1 to 3 and from 23 to 25 species respectively and from seven to eight families (Sapindaceae being a new record to this age, see Results part). Subfamily Faboideae is also a new record to the Miocene age of Egypt (see Introduction part).

Fossil wood anatomy and the Nearest Living Relatives (NLR) are good tools for the reconstruction of palaeoclimate and size of woody plants. The xylotomical characters used are: growth rings, porosity, vessel diameter, vessel grouping, vessel frequency and axial parenchyma. The 
main wood features of $D$. dicoryniodes are: indistinct growth rings, diffuseporosity, wide vessels often solitary, low vessel frequency and abundant axial parenchyma indicating nonseasonal tropical (lowland) palaeoclimate (see Wheeler \& Baas, 1991, 1993; Woodcock \& Ignas, 1994; Alves \& Angyalossy-Alfonso, 2000, 2002; Martínez, 2014). The main wood features of $S$. stromeri are: indistinct growth rings, diffuse-porosity, narrow vessels often multiples, high vessel frequency and scanty axial parenchyma indicating nonseasonal high montane tropical or cool temperate palaeoclimate (see Alves \& Angyalossy-Alfonso, 2000). Shrubs and small trees do not have wide vessels (Wheeler \& Baas, 1993). The two described species, therefore, appear to indicate different climates. It may be: 1- They grew in one tropical area but at different heights, $D$. dicoryniodes grew in the lowland whereas $S$. stromeri in the high montane. 2- They grew in one tropical area and at same elevation but $D$. dicoryniodes was a large tree while $S$. stromeri was a shrub or small tree. This latter speculation is probably the correct one for the following: The $\mathrm{V}$ value (mean vessel tangential diameter/mean number of vessels per $\mathrm{mm}^{2}$ ) of $D$. dicoryniodes and S. stromeri are 21.4 and 2.3 respectively. The high V value of $D$. dicoryniodes indicates tropical and large trees (Baas et al., 1983). Shallow rooted shrubs and small trees in the tropics have low V value (Wolfe \& Upchurch, 1987). Mean vessel tangential diameter and mean number of vessels per $\mathrm{mm}^{2}$ are related to size of woody plants. Mean vessel tangential diameter is highest in large trees $(170 \mu \mathrm{m}$ in $D$. dicoryniodes while $75 \mu \mathrm{m}$ in $S$. stromeri) and mean number of vessels per $\mathrm{mm}^{2}$ is highest in shrubs and small trees $\left(32 / \mathrm{mm}^{2}\right.$ in $S$. stromeri while $8 / \mathrm{mm}^{2}$ in $D$. dicoryniodes) (Wolfe \& Upchurch, 1987). The conductive capability $C\left(\mathrm{r}^{4} / 10^{6} \mathrm{x}\right.$ mean number of vessels per $\mathrm{mm}^{2}, \mathrm{r}$ is the radius of the vessel) of $D$. dicoryniodes and $S$. stromeri are 417.6 and 63.2 respectively. High $C$ values are found only in large trees (Wolfe \& Upchurch, 1987). The NLR of $D$. dicoryniodes (which is apparently a large tree) is Dalbergia which is found in tropical forests and savannas of Africa, South America and South Asia (Tiwari et al., 2012) and is known to be a large tree. The NLR of S. stromeri (which a is apparently a shrub or a small tree) is Arytera (trees and shrubs) rather than Mischocarpus (trees) however, both grow in Southeast Asia, Central south Asia, Pacific Islands, Australia and New Zealand (Insidewood 2004-onwards). 


\section{References}

Alves, E.S. and Angyalossy-Alfonso, V. 2000. Ecological trends in the wood anatomy of some Brazilian species. 1. Growth rings and vessels. IAWA J. 21: 3-30.

Alves, E.S. and Angyalossy-Alfonso, V. 2002. Ecological trends in the wood anatomy of some Brazilian species. 2. Axial parenchyma, rays and fibers. IAWA J. 23: 391-418.

Andrews, H.N. 1961. Studies in palaeobotany. Wiley, New York and London, pp. 1-487.

APG III. 2009. An update of the Angiosperm Phylogeny Group classification for the orders and families of flowering plants. Bot. J. Linn. Soc. 161: 105-121.

Bamford, M.K. and De Wit, C.J. 1993. Taxonomic description of fossil wood from Cainozoic Sak River terraces, near Brandvlei, Bushmanland, South Africa. Palaeontologia Africanna 30: 71-80.

Beauchamp, J., Lemoigne, Y. and Petrescu, J. 1973a. Age de différents niveaux du complexe volcanique des Trappes: Debré-Libanos (Province du Shoa, Ethiopie), d'apre l'etude des Paléoflores. C.R. Acad. Sci. Paris D 276 (9): 1409-1412.

Beauchamp, J., Lemoigne, Y. and Petrescu, J. 1973b. Le paléoflores tertiaries de Debré-Libanos (Ethiopie). Ann. Soc. Géol. Nord 93: 1732.

Bromhead, E.F. 1838. An attempt to ascertain characters of the botanical alliances. Edinburgh New Philosophical Journal 25: 123-135.

Burgh, J. van der. 1973. Hölzer der niederrheinischen Braunkohlenformation. 2. Hölzer der Braunkohlengruben "Maria Theresia" zu Herzogenrath. "Zukunft West" zu Eschweiler und "Victor" (Zulpich Mitte) zu Zulpich. Nebst einer systematischanatomischen Bearbeitung der Gattung Pinus L. Rev. Palaeobot. Palynol. 15: 73-275.

Cantrill, D.J., Bamford, M.K., Wagstaff, B.E. and Sauquet, H. 2013. Early Eocene fossil plants from the Mwadui kimberlite pipe, Tanzania. Rev. Palaeobot. Palynol. 196: 19-35.

Carlquist, S. 1977. Ecological factors in wood evolution. A Floristic Approach. Amer. J. Bot. 64 (7): 887-896. 
Chaney, R.W. 1933. A Tertiary flora from Uganda. J. Geol., 41: 702-709.

Damblon, F., Gerrienne, P., D'Outrelpont, H. Delvaux, D., Beeckman, H. and Back, S. 1998. Identification of a fossil wood specimen in the Red Sandstone Group of southwestern Tanzania: stratigraphical and tectonic implications. J. S. Afr. Earth Sci. 26: 387-396.

De Jussieu, A.L. 1789. Genera plantarum secundum ordines naturales disposita. A.V. erissant and T. Barrois, Paris, 522 pp.

Dumortier, B.C.J. 1829. Analyse des familles des plantes, avec l'indication des principaux genres qui s'y rattachent. Imprimerie de J. Casteman Aîné, Tournay, 104 pp.

Dupéron, J. 1979. Sur un bois fossile de Leguminosae de la Molasse de l'Agenais (Stampien). C.r. 104e Congr. Nat. Soc. Sav., Bordeaux, Sci. 1: 291-299.

Dupéron-Laudoueneix, M. and Dupéron, J. 1995. Inventory of Mesozoic and Cenozoic woods from Equatorial and North Equatorial Africa. Rev. Palaeobot. Palynol. 84: 439-480.

El-Saadawi, W., Kamal El-Din, M.M., Attia, Y. and El-Faramawi, M.W. 2011. The wood flora of the Cairo Petrified Forest, with five Paleogene new legume records for Egypt. Rev. Palaeobot. Palynol. 167: 184-195.

El-Saadawi, W. ,Kamal El-Din, M.M., Wheeler, E., Osman, R., ElFaramawi, M.W. and El-Noamani, Z. 2014. Early Miocene woods of Egypt. IAWA J. 35 (1), 35-50.

El-Saadawi, W., Youssef, S. and Kamal El-Din, M.M. 2002. Fossil palm woods of Egypt: I. Palmoxylon aschersoni Schenk and P. libycum (Stenzel) Kräusel. Taeckholmia 22: 143-153.

El-Saadawi, W., Youssef, S. and Kamal El-Din, M.M. 2004. Fossil palm woods of Egypt: II. Seven Tertiary Palmoxylon species new to the country. Rev. Palaeobot. Palynol. 129: 199-211.

Fliche, P. 1888. Sur les bois silicifiés de la Tunisie et de l'Algérie. C.r. Acad. Sci., Paris 107: 569-572.

Gregory, M., Poole, I. and Wheeler, E.A. 2009. Fossil dicot wood names an annotated list with full bibliography. IAWA J., supplement 6: 1220.

Gros, J.P. 1992. A synopsis of the fossil record of mimosoid legume wood. pp. 69-83 in: Herendeen, P.S. and Dilcher, D.L. (eds.), Advances in Legume systematic. Part 4. The Fossil Record. The Royal Botanic Gardens, Kew. 
Herendeen, P.S., Crepet, W.L. and Dilcher, D.L. 1992. The fossil history of the Leguminosae: Phylogenetic and biogeographic implications. pp. 303-316 in: Herendeen, P.S. and Dilcher, D.L. (eds.), Advances in Legume systematic. Part 4. The Fossil Record. The Royal Botanic Gardens, Kew.

IAWA Committee. 1989. IAWA list of microscopic features for hardwood identification. IAWA J., 10: 219-332.

Insidewood, 2004-onwards. Published on the Internet. http://insidewood.lib.ncsu.edu/search;jsessionic.

Kamal El-Din, M.M. 1999. Studies on petrified palms from Egypt. Ph. D. Thesis. Bot. Dept., Fac. of Sci., Ain Shams Univ., Cairo, Egypt, pp. $1-234$.

Kamal El-Din, M.M., Darwish, M. \& El-Saadawi, W. 2014. Novelties on Miocene woods from Egypt with a summary on African fossil woods of Fabaceae, Malvaceae and Dipterocarpaceae. Palaeontographica B: (In press)

Koeniguer, J.C. 1967a. Etude paléoxylologique du Rio de Oro. Not. Com. Inst. Geol. Min. Esp., 96: 39-66.

Koeniguer, J.C. 1967b. Etude paléoxylologique de la Libye. I. Sur un bois fossile de l'Oligocène de Dar el Abd (Syrte): Bridelioxylon arnouldii n. sp. II. Sur la présence de Dombeyoxylon owenii (Carr.) kräusel, 1939, dans le Tertiaire de la Syrte. III. Sur la présence de Sapindoxylon sp. dans le Tertiaire du Nord du Tibesti. C.r. 91e Congr. Nat. Soc. Sav., Rennes, 1966. Paris, Sci. 3: 153-172.

Koeniguer, J.C. 1968. Les structures ligneuses néogènes du Tchad. Mém. Sect. Sci. CTHS Paléobot., 2: 112-129.

Koeniguer, J.C. 1973. Sur un bois fossile de l'Eocène de Mbao (Sénégal). Bull. IFAN, A, 35 (3): 502-508.

Koeniguer, J.C. 1974. Les bois fossiles de Tamarix, d'Acacia et de Retama du Plio-Quaternaire saharien.C.R. Acad. Sci. Paris, D, 278 (24): 3069-3072.

Koeniguer, J.C. 1975. Sur deux bois fossiles du Quaternaire de l'Angamma (Tchad). Actes 98e Congr. Nat. Soc. Sav., Saint-Etienne, 1973. Paris, Sci. 2: 41-46.

Koeniguer, J.C. 1976. Sur quelques dois fossiles du Tertiaire de l'Algérie. Actes 97e Congr. Nat. Soc. Sav., Nantes, 1972. Paris, Sci. 4: 45-65.

Kräusel, R. 1922. Fossile hölzer aus dem Tertiär von Süd-Sumatra. Verh. Geol. Mijnbouwkund. Genoot. Ned. Kolon. 5: 231-287. 
Kräusel, R. 1939. Ergebnisse der Forschungsreisen Prof. E. Stromers in den Wüsten Ägyptens, IV. Die fossilen Floren Ägyptens: Die Fossilen Pflanzen Ägyptens. E-L Abh. Bayer. Akad. Wiss., Math.-Nat. Abt. N. F. 47: 1-140.

Klitzsch, E. and Lejal-Nicol, A. 1984. Flora and fauna from strata in Southern Egypt and Northern Sudan (Nubia and surrounding areas). Berliner geowiss. Abh. (A) 50: 47-79.

Lemoigne, Y. 1970. Etude paléoxylolgique de l'Ethiopie: B. Présence du genre Sapindoxylon dans le Tertiaire d'Ethiopie: Sapindoxylon hailesellassiei n. sp. Bull. Mens. Soc. Linn. Lyon, 39 (4): 126-131.

Lemoigne, Y. 1978. Flores tertiaires de la haute vallée de L'Omo (Ethiopie). Palaeontographica Abt. B 165 (4-6): 89-157.

Lemoigne, Y., Beauchamp, J. and Samuel, E. 1974. Etude paléobotanique des dépôts volcaniques d'âge tertiaire des bordures est et oust du système des rifts éthiopiens. Geobios, 7 (3): 267-288.

Lindley, J. 1836. An Introduction to the Natural System of Botany. Longman, Rees, Orme, Brown, and Green, London.

Martínez, L.C. 2014. Fossil legume woods from the Late Miocene, Chiquimil Formation (Santa María Basin), Argentina. Rev. Palaeobot. Palynol. 201: 1-11.

Metcalfe, C.R. and Chalk, L. 1950. Anatomy of dicotyledons. Oxford. 1, pp. 1-724.

Mehrotra, R.C., Awasthi, N. and Dutta, S.K. 1999. Study of fossil wood from the upper Tertiary sediments (Siwalik) of Arunachal Pradesh, India and its implication in palaeoecological and phytogegraphica interpretations. Rev. Palaeobot. Palynol. 107: 223-247.

Müller-Stoll, W.R. and Mädel, E. 1967. Die fossilen LeguminosenHölzer. Eine Revision der mit Leguminosen verglichenen fossilen Hölzer und Beschreibungen älterer und neuer Arten. Palaeontographica B 119: 95-174.

Müller-Stoll, W.R. and Mädel-Angeliewa, E. 1986. Ein neues GuttiferenHolz aus dem Tertiär von Java, Calophylloxylon intermedium sp. nov. Feddes Repert. 97: 225-233.

Navale, G.K. 1957. Sapindoxylon sp. nov., a new fossil wood from the Tertiary beds of south India. Palaeobotanist 5: 73-77.

Pearson, R.S. and Brown, H.P. 1932. Commercial Timbers of India, vols. 1 and 2. Government of India, Central Publication Branch, Calcutta, $600 \mathrm{pp}$. 
Ramanujam, C. 1960. Silicified woods from the Tertiary of South India. Palaeontographica B 106: 99-140.

Rudd, V.E. 1972. Leguminosae-Faboideae-Sophoreae. N. Amer. Fl., ser. 2 (7): 1-53.

Said, R. 1962. The geology of Egypt. Elsevier, Amsterdam.

Said, R. 1971. Explanatory notes to accompany the geological map of Egypt. The Geological Survey of Egypt 56: 1-123.

Schenk, A. 1883. Fossile Hölzer. Palaeontographica 30(2): 1-19.

Tiwari, R.P., Mehrotra, R.C., Srivastava, G. and Shukla, A. 2012. The vegetation and climate of a Neogene petrified wood forest of Mizoram, India. Journal of Asian Earth Sciences 61: 143-165.

Wheeler, E. A. and Baas, P. 1991. A survey of the fossil record for dicotyledonous wood and its significance for evolutionary and ecological wood anatomy. IAWA Bull., n. s. 12: 275-332.

Wheeler, E. A. and Baas, P. 1992. Fossil wood of the Leguminosae: a case study in xylem evolution and ecological anatomy. pp. 281-301 in: Herendeen, P.S. and Dilcher, D.L. (eds), Advances in legume systematics, Part 4. The fossil record. Royal Botanic Gardens, Kew.

Wheeler, E. A. and Baas, P. 1993. The potentials and limitations of dicotyledonous wood for climatic reconstruction. Paleobiology 19: 487-498.

Wheeler, E., Wiemann, M.C. and Fleagle, J.G. 2007. Woods from the Miocene Bakate Formation, Ethiopia. Anatomical characteristics, estimates of original specific gravity and ecological inferences. Rev. Palaeobot. Palynol. 146: 193-207.

Wolfe, J.A. and Upchurch, G.R. 1987. North American non-marine climates and vegetation during the Late Cretaceous. Palaeogeogr. Palaeoclimatol. Palaeoecol. 61: 33-77.

Woodcock, D.W. and Ignas, C.M. 1994. Prevalence of wood characters in eastern North America: what characters are most promising for interpreting climates from fossil wood? Amer. J. Bot. 81: 1243-1251. 


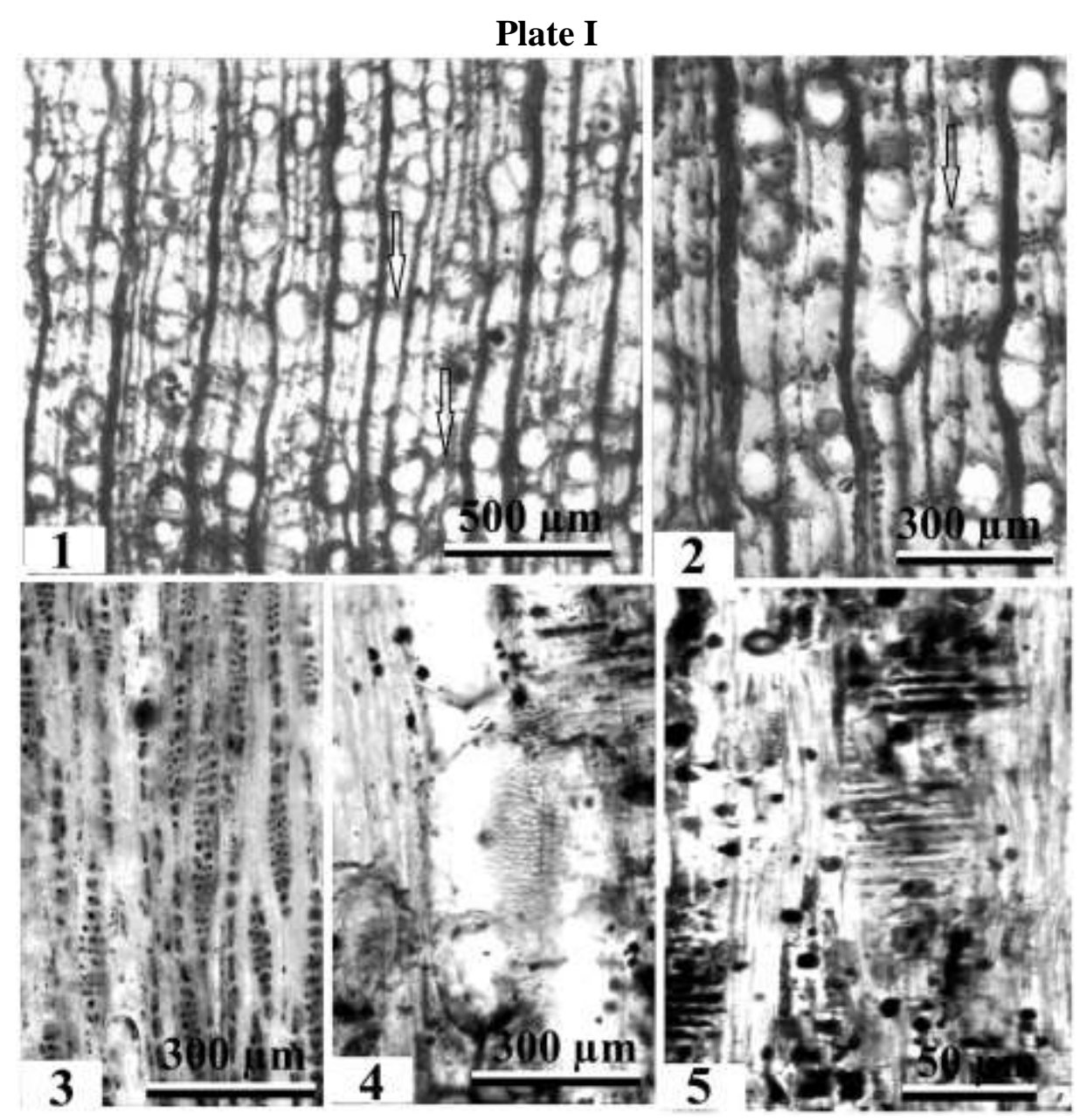

Plate I. Dalbergioxylon dicorynioides. 1: Cross section showing diffuseporous wood, rounded vessels and banded parenchyma (arrows), 2: Cross section magnified to show aliform parenchyma (arrow), 3: Tangential longitudinal section showing 1-3 seriate rays, 4: Longitudinal section showing alternate intervessel pits, 5: Radial longitudinal section showing homocellular rays. 


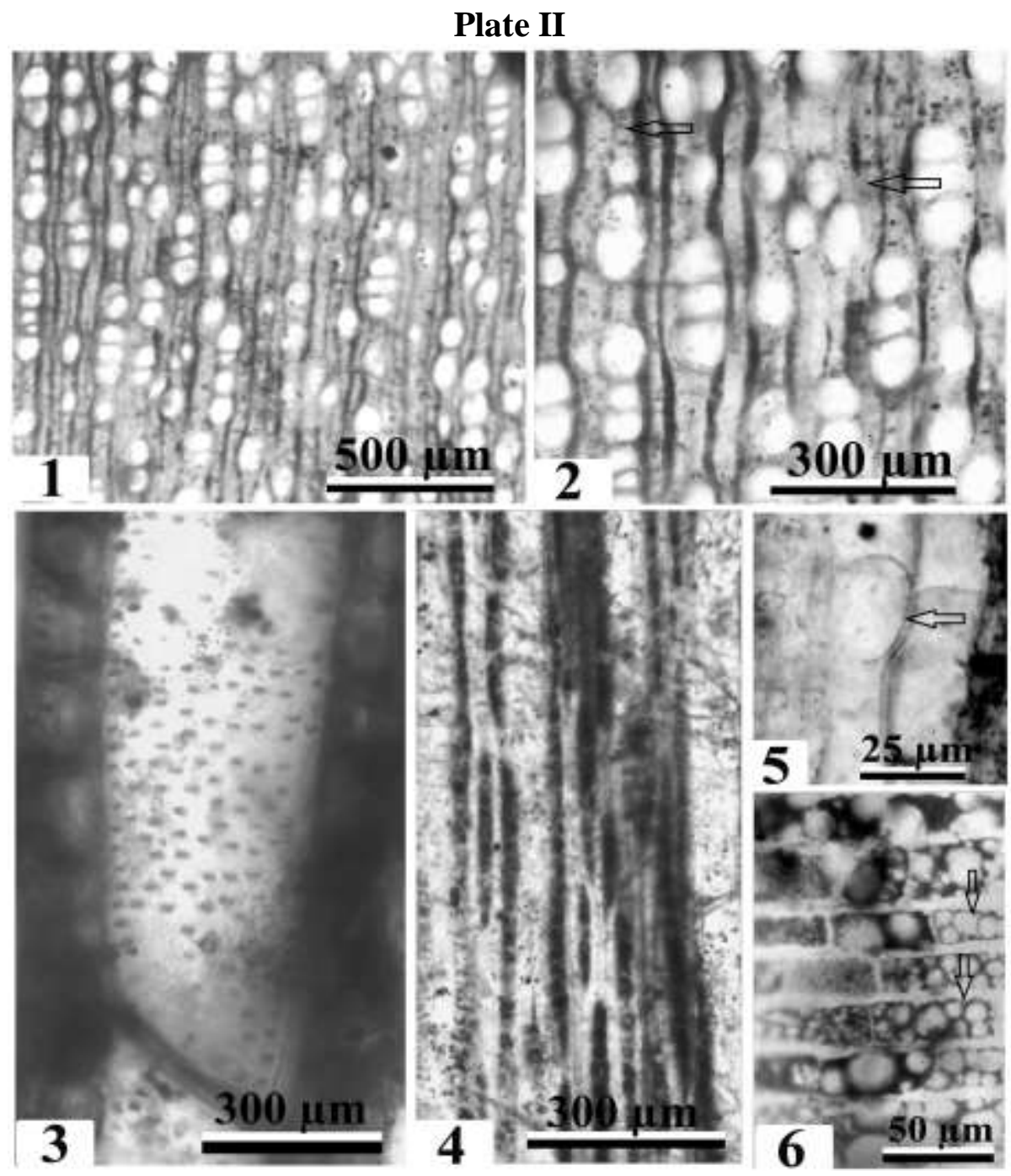

PlateII. Sapindoxylon stromeri. 1: Cross section showing diffuse-porous wood, solitary vessels and 2-5 multiples of vessels, 2: Cross section showing thick-walled fibers (arrows) and scanty parenchyma, 3: Longitudinal section showing alternate intervessel pits, 4: Tangential longitudinal section showing mostly uniseriate rays, 5: Longitudinal section showing simple perforation plate (arrow), 6: Radial longitudinal section showing homocellular rays and crystals (arrows). 